\title{
EVALUASI PENERAPAN KATEGORI DAN TUJUAN KOTA TANGGUH PADA DOKUMEN KEBIJAKAN STRATEGI KETAHANAN KOTA 100 RESILIENT CITY
}

\author{
Salmaa Shafira, Jamilla Kautsary, Hasti Widyasamratri, Boby Rahman \\ Program Studi Perencanaan Wilayah dan Kota Universitas Islam Sultan Agung \\ E-mail Korespodensi: afirasalmaa25@gmail.com
}

\begin{abstract}
100 Resilient City is an activity program pioneered by the Rockefeller Foundation which is intended to help cities become strong cities in the face of physical, social, and economic shocks and battles that developed in the 21st century. Cities that have been chosen as 100 Resilient City has a resilient city resilience strategy policy document. 100 Resilient City is indicated not to apply the theory/concept of the category and the purpose of 100 Resilient City. The purpose of this study is to examine and allocate the theory/concept of categories and strong city goals in the strategic policy document of 100 Resilient City. The method used is a qualitative rationalistic deductive method. After evaluating the policy documents of 100 Resilient City, it was found that it did not apply the tough city category and purpose. This can occur because of the situation of the city with different shocks and challenges so that it can influence the application of theory/concept categories and city goals
\end{abstract}

Keywords: Evaluation, Resilient City, Strategy Policy Document of 100 Resilient City, 100 Resilient City

\begin{abstract}
Abstrak
Kota 100 Resilient City adalah program kegiatan yang dipelopori oleh Yayasan Rockefeller yang bertujuan untuk membantu kota-kota agar menjadi kota yang tangguh dalam menghadapi guncangan dan tantangan fisik, sosial, dan ekonomi yang berkembang pada abad ke 21. Kota yang telah terpilih sebagai 100 Resilient City mempunyai dokumen kebijakan strategi ketahanan kota tangguh. Namun pada dokumen kebijakan strategi ketahanan yang dimiliki Kota 100 Resilient City terindikasi tidak menerapkan teori/konsep kategori dan tujuan kota tangguh. Tujuan dari penelitian ini adalah untuk mengkaji dan mengalisis teori/konsep kategori kota tangguh dan tujuan kota tangguh pada dokumen kebijakan strategi Kota 100 Resilient City. Metode yang digunakan adalah metode deduktif kualitatif rasionalistik. Setelah melakukan evaluasi pada dokumen kebijakan strategi ketahanan 100 Resilient City ditemukannya tindakan tidak menerapkan kategori dan tujuan kota tangguh. Hal ini dapat terjadi dikarenakan kondisi kota dengan guncangan dan tantangan yang berbeda-beda sehingga dapat mempengaruhi penerapan teori/konsep kategori dan tujuan kota tangguh.
\end{abstract}

Kata Kunci: Evaluasi, Kota Tangguh, Dokumen Kebijakan Strategi Ketahanan, Kota 100 Resilient City 


\section{PENDAHULUAN}

Kota tangguh sedang ramai digaungkan saat ini, begitu pula dengan adanya gagasan 100 Resilient City atau 100 Kota Tangguh yang dipelopori oleh Rockefeller Foundation atau Yayasan Rockefeller pada tahun 2013. Kota yang tangguh atau kota yang berketahahan menggambarkan kapasitas dan fungsi orang-orang yang tinggal di kota, terutama yang miskin dan rentan untuk menghadapi guncangan dan tekanan yang dihadapi (Arup International Development, 2015). Kota yang berketahanan memiliki prinsip dan kriteria utama perencanaan ketahanan kota meliputi infrastruktur yakni air, energi, konfirgurasi dan lokasi spasial, tansportasi, infrastruktur hijau, struktur pertahanan, perlindungan, bangunan dan design, lalu teknologi dan informasi, keamanan, dan lingkungan yang meliputi ekosistem,ekonomi. lembaga (perencanaan, pemerintahan), sosial dan demografi yang meliputi kesehatan (Sharifi \& Yamagata, 2014).

Ketahanan kota juga dapat diartikan keterampilan teritori dan komunitas untuk mencegah, menghargai dengan benar segala masalah lingkungan dan sosial dari bencana alam hingga dampak perubahan iklim hingga kemiskinan, dan sebuah kota dicirikan sebagai kota berketahanan ketika kota berubah dengan membangun sosial, ekonomi, dan lingkungan serta sejarah yang baru (D’Ascanio, Di Ludovico, \& Di Lodovico, 2016). Dalam mengembangkan kerangka kota yang tangguh dapat menggunakan pendekatan berbasis tempat yang menggabungkan pemikiran untuk perubahan sebagai proses yang dinamis melintasi skala waktu dan dengan memahami hubungan antara orang-orang dan tempat mereka (Mirti Chand, 2018). Selain itu, ketahanan memberikan dasar konseptual untuk teori dan praktik yang ditujukan untuk meningkatkan manajemen dalam Sosial Ekonomi Sistem (SES). Hal ini termasuk pengelolaan bersama, tata kelola adaptif. Saat ini, pengelolaan bersama adaptif dan praktik-praktik berupaya mengatasi tantangan manajemen di daerah aliran sungai dan ekosistem pertanian (Orleans Reed et al., 2013).

Kota Tangguh telah mengambil langkah-langkah untuk mengantisipasi dan mengurangi konsekuensi dari bencana, menggabungkan teknologi pemantauan dan peringatan dini untuk melindungi infrastruktur, aset masyarakat dan individu, termasuk rumah dan harta benda mereka, warisan budaya, modal lingkungan dan ekonomi, dan mampu meminimalkan fisik dan fisik. Kerugian sosial yang timbul dari peristiwa cuaca ekstrem, gempa bumi atau 
bahaya alam atau buatan manusia lainnya (Kováčová, Pavlenko, Titko, Mitašová, \& Havko, 2017). Dalam hal ini, untuk menyajikan lingkungan perkotaan dunia nyata yang menantang di mana untuk secara kolaboratif dan komputasi mengeksplorasi bagaimana perencanaan infrastruktur kritis dapat ditingkatkan dengan identifikasi dan analisis yang tepat dari langkahlangkah ketahanan saat ini dan konteks pengaruh khusus seperti polderisasi dan dioperasionalkan dengan pemikiran kumpulan diletakkan pada perencanaan lingkungan kota (Ali, Ingirige, \& Zainal Abidin, 2018). Hal ini dikarenakan adanya kerentanan terhadap dampak perubahan iklim tidak terbatas pada lingkungan yang dibangun, tetapi meluas ke sistem sosial teknis yang mencakup persepsi, nilai-nilai, preferensi, dan pola perilaku berbagai kelompok pemangku kepentingan manusia. Untuk lebih sepenuhnya memasukkan dimensi manusia ke dalam perencanaan ketahanan, kita harus memperoleh dan menerapkan kebijakan ekologi dari penduduk lokal dan pemangku kepentingan (Douglas, Reardon, \& Täger, 2018). Sehingga dalam hal ini konsep kota yang berketahanan atau kota yang resilient dapat menghadapi tekanan dan guncangan dari kegiatan alam.

Sebagaimana menurut Douglas, Readon, dan Täger (2018), konsep kebijakan ekologi dapat digunakan sebagai masukan pengetahuan lokal yang dpaat diperoleh untuk menginformasikan adaptasi perubahan iklim perkotaan dan perencanaan ketahanan. Pemenuhan konsep kota tangguh atau kota berketahanan memerlukan strategi dalam kebijakan yang juga bersifat tangguh. Kebijakan tangguh dipersiapkan untuk mencegah bencana mitigasi kerusakan yang dilaksanakan melalui regulasi dan kerja sama publik dan swasta (Lee, Chun, \& Song, 2018). Sebagaimana yang berorientasi pada masa depan suatu kota dapat disebut sebagai kota yang berketahanan atau resilient city jika memiliki orientasi fokus yang khusus. Penelitian di masa depan akan fokus pada tiga bidang terutama, seperti jasa ekosistem, kapasitas adaptif dan ekosistem yang didominasi manusia. Dengan pengembangan kota global, lebih banyak topik akan diperhatikan, seperti metrik ketahanan perkotaan, hubungan antara kota rekreasi dan kota tangguh, kerentanan perkotaan dan ketahanan kota (Pu \& Qiu, 2016).

Secara khusus, pemahaman tentang kerentanan dapat membantu mengidentifikasi komponen yang lemah dari suatu sistem dengan mengadopsi langkah-langkah yang sesuai membuat kota lebih tangguh terhadap dampak bencana (Kováčová et al., 2017). Dalam membentuk suatu kota yang berketahanan dapat menggunakan model kedewasaan ketahanan, terdapat Resilience Maturity Model (RMM) atau Model Kematangan Ketahanan yang dapat 
memandu kota dalam proses ketahanan dengan memberikan peta jalan kota dengan lima tahap kematangan untuk membangun secara sistematis dan bertahap, adapaun lima tahap itu yaitu mulai, sedang, maju, kuat, dan bertulang belakang (Hernantes, Sarriegi, Labaka, Maraña, \& Gimenez, 2018). Kebijakan pendekatan upaya ketahanan suatu kota menjadi resilient city memerlukan dukungan dari pemangku kebijakan yang merupakan kunci bergeraknya suatu proses efektivitas (Hernantes et al., 2018). Sehingga dapat diketahui bahwa sebagian besar, pengetahuan ahli digunakan untuk mengembangkan rencana strategis serta hubungan yang baik antara para pemangku kepentingan dalam pengelolaan air, perencanaan tata ruang, dan manajemen bencana (Wals, 2015).

Suatu kota dianggap dapat menjadi kota yang berketahanan jika mampu bersikap tangguh dalam menghadapi tekanan dan guncangan, hal juga dalam beradaptasi dengan perubahan iklim. Bentuk penyesuaian ini berpedoman pada perbuatan yang meminimalisir pengaruh buruk dari perubahan iklim serta menimbulkan pengaruh yang memberikan manfaat baru (Wijaya, 2015). Selain itu, diperlukan adanya pengaturan perkotaan serta perencanaan dalam menciptakan kota tangguh dengan perencanaan terintegrasi (Sariffuddin, 2015). Hal ini juga didukung dengan adanya 100 Kota Tangguh yang memberikan pentingnya strategi terintegrasi dengan menetapkan analisis fokus area (Setiadi \& Wulandari, 2017). Dalam mendukung kota yang tangguh juga diperlukan dukungan dari kelembagaan suatu kota. Dengan adanya pedoman dari kelembagaan pemerintah dan kerjasama dengan lembaga terkait maka akan memudahkan dalam mewujudkan tujuan bersama (Eko Budi Santoso, 2013). Adanya suatu kerjasama dengan lembaga atau kelompok masyarakat maka dapat memudahkan suatu penyebaran informasi dari pemerintah ke masyarakat (Yesiana, Handayani, Anggraini, Vokasi, \& Teknik, 2018).

Pembentukan 100 Kota Tangguh atau 100 Resilient City memiliki tujuan untuk membantu agar kota menjadi tangguh terhadap guncangan dan tantangan yang dihadapi tiap masing-masing kota terutama yang rentan terhadap bencana. Sebagai upaya untuk menghadapi guncangan dan tantangan tersebut, kota yang termasuk 100 Resilient City ini mempunyai keluaran berupa instrumen dokumen kebijakan strategi ketahanan kota yang dibuat berdasarkan kerjasama dengan Rockefeller Foundation. 
Dokumen ini menjadi alat pegangan untuk menghadapi guncangan dan tantangan yang dimiliki oleh 100 Kota Tangguh, didalam dokumen ini terdapat strategi-strategi yang dimiliki tiap kota tangguh yang meliputi kategori dan tujuan kota tangguh sesuai dengan teori/konsep dari Rockefeller Foundation. Kategori dan tujuan kota tangguh ini yang menjadi dasar kerangka strategi ketahanan yang dimiliki oleh 100 Kota Tangguh atau 100 Resilient City, sehingga dengan memiliki dokumen kebijakan strategi ketahanan ini dapat mendukung 100 Kota Tangguh ini menjadi tangguh dalam menghadapi tantangan dan guncangan yang dihadapinya.

Namun, setelah meninjau dokumen strategi ketahanan Kota 100 Resilient City, ternyata ditemukan indikasi 100 Resilient City tidak menerapkan teori/konsep kategori dan tujuan kota tangguh pada instrumen dokumen kebijakan tersebut, sehinga diperlukan evaluasi penerapan kategori dan tujuan kota tangguh pada Kota 100 Resilient City. Sebagaimana yang diketahui bahwa Thomas Dye mengartikan evaluasi sebagai tindakan pemeriksaan yang dilakukan secara objektif dan sistematis serta empiris terhadap efek dari kebijakan dan program publik terhadap targetnya dari segi tujuan yang ingin dicapai (Wayne Parson, 2006). Selain itu, evaluasi terhadap kebijakan juga dapat diartikan sebagai tahap akhir dalam proses kebijakan publik untuk mengetahui jangkauan kebijakan tersebut telah dilaksanakan sudah menghasilkan dampak yang diinginkan atau belum (Brito, 2013). Keberhasilan suatu implementasi dapat dilihat melalui dua cara menurut Patton, C.V. dan Sawicki (1986) yakni evaluasi pengaruh pembangunan/evaluasi proses (formative evaluation atau process evaluation) merupakan studi proses implementasi proyek untuk menilai seberapa efektif sebuah proyek tersebut diimplementasikan dan evaluasi sumatif (summative evaluation) yang merupakan penilaian sampai seberapa jauh sebuah proyek telah menghasilkan dan sejauh mana perubahan yang teramati dapat dihasilkan oleh kehadiran proyek-proyek.

Berdasarkan penjelasan sebelumnya maka dapat diketahui bahwa penyusunan studi ini terkait dengan evaluasi penerapan kategori dan tujuan kota tangguh pada Dokumen Kebijakan Strategi Ketahanan Kota 100 Resilient City, yang terdapat beberapa permasalahan yaitu adanya indikasi bahwa terdapat Kota 100 Resilient City yang belum menerapkan teori/konsep kategori kota tangguh dan adanya indikasi bahwa terdapat Kota 100 Resilient City yang belum menerapkan teori/konsep tujuan kota tangguh. 
Tujuan dari penelitian ini adalah untuk mengkaji dan mengalisis teori/konsep kategori kota tangguh dan tujuan kota tangguh pada dokumen kebijakan strategi Kota 100 Resilient City sehingga berkaitan dengan evaluasi penerapan kategori dan tujuan kota tangguh pada Kota 100 Resilient City. Guna mencapai tujuan dalam penelitian dilakukan beberapa sasaran yakni menemukan parameter dan variabel yang digunakan untuk mengevaluasi penerapan kategori dan tujuan kota tangguh pada dokumen kebijakan strategi ketahanan Kota 100 Resilient City dan menverifikasi parameter dan variabel yang digunakan untuk mengevaluasi penerapan kategori dan tujuan kota tangguh pada dokumen kebijakan strategi ketahanan Kota 100 Resilient City.

Penelitian ini menggunakan metode deduktif kualitatif rasionalistik yang artinya bahwa metode ini didasarkan pada pengkajian yang ditemukan pada dokunen kebijakan strategi ketahananan Kota 100 Resilient City dan sesuai dengan teori/konsep terkait dengan evaluasi penerapan kategori dan tujuan kota tangguh pada Kota 100 Resilient City.

\section{PEMBAHASAN}

Bentuk evaluasi penerapan kategori dan tujuan kota tangguh pada dokumen kebijakan strategi ketahanan Kota 100 Resilient City ini menggunakan konsep berupa kota tangguh, dengan menggunakan parameter berupa kategori dan tujuan kota tangguh.

Adapun menurut Lembaga Arup Internasional yang termasuk dalam Yayasan Rockefeller atau Rockefeller Foundation kota yang tangguh memiliki empat kategori yaitu kepemimpinan dan strategi, kesehatan dan kesejahteraan, ekonomi dan sosial, infrastruktur dan lingkungan. Sedangkan untuk tujuan kota yang tangguh meliputi memajukan kepemimpinan dan manajemen yang efektif; memberdayakan berbagai macam pemangku kepentingan, membantu perkembangan jangka panjang dan perencanaan terpadu; memenuhi kebutuhan dasar; mendukung mata pencaharian dan pekerjaan; memastikan layanan kesehatan masyarakat; memajukan komunitas yang kohesif dan terlibat; memastikan stabilitas sosial, keamanan, dan keadilan; membantu perkembangan kesejahteraan ekonomi; menyediakan dan meningkatkan asset pelindung alam dan asset buatan manuasia; memastikan kesinambungan dari layanan kritis; dan memberikan komunikasi dan mobilitas yang andal, kategori dan tujuan ini memiliki keterkaitan satu sama yang lainnya (Arup International Development, 2015). 
Penelitian ini menggunakan studi kasus Kota 100 Resilient City yaitu Kota Semarang di Indonesia dengan menggunakan Dokumen Kebijakan Strategi Kota Semarang Tahun 2016, Kota Bangkok di Thailand dengan menggunakan Dokumen Kebijakan Strategi Kota Bangkok Tahun 2017 , dan Kota Surat di India dengan menggunakan Dokumen Kebijakan Strategi Kota Surat Tahun 2017. Hal ini dapat dijelaskan pada tabel berikut ini: 
Tabel 1. Matrik Temuan Studi Kasus Evaluasi Penerapan Kategori dan Tujuan Kota Tangg Kebijakan Strategi Ketahahanan Kota 100 Resilient City

\begin{tabular}{|c|c|c|c|c|c|}
\hline Konsep & Parameter & Variabel & $\begin{array}{c}\text { Penerapan Kategori } \\
\text { Kota Tangguh dan } \\
\text { Tujuan Kota Tangguh } \\
\text { di Kota Semarang, } \\
\text { Indonesia }\end{array}$ & $\begin{array}{c}\text { Penerapan Kategori } \\
\text { Kota Tangguh dan } \\
\text { Tujuan Kota Tangguh } \\
\text { di Kota Bangkok, } \\
\text { Thailand } \\
\end{array}$ & $\begin{array}{r}\text { Penerapan } \\
\text { Kota Tan } \\
\text { Tujuan } \\
\text { Tangguh } \\
\text { Surat, } \\
\end{array}$ \\
\hline \multirow{4}{*}{ Kota Tangguh } & \multirow[t]{4}{*}{$\begin{array}{l}\text { Kategori Kota } \\
\text { Tangguh }\end{array}$} & $\begin{array}{l}\text { Kepemimpinan } \\
\text { dan strategi }\end{array}$ & $\begin{array}{l}\text { Transparansi informasi } \\
\text { publik dan tata } \\
\text { pemerintahan }\end{array}$ & $\begin{array}{l}\text { Mengurangi resiko dan } \\
\text { meningkatkan adaptasi }\end{array}$ & \\
\hline & & $\begin{array}{l}\text { Kesehatan dan } \\
\text { kesejahteraan }\end{array}$ & $\begin{array}{l}\text { Resiko dampak bencana } \\
\text { dan wabah penyakit, } \\
\text { mobilitas terpadu, } \\
\text { peluang dan ekonomi } \\
\text { baru }\end{array}$ & $\begin{array}{l}\text { Meningkatkan kualitas } \\
\text { hidup }\end{array}$ & $\begin{array}{l}\text { Meningkatk } \\
\text { kesehatan di } \\
\text { perumahan } \\
\text { terjangkau }\end{array}$ \\
\hline & & $\begin{array}{l}\text { Ekonomi dan } \\
\text { sosial }\end{array}$ & $\begin{array}{l}\text { Peluang dan ekonomi } \\
\text { baru dan SDM berdaya } \\
\text { saing }\end{array}$ & $\begin{array}{l}\text { Menggerakkan ekonomi } \\
\text { yang kuat dan } \\
\text { kompetitif, dan } \\
\text { Meningkatkan kualitas } \\
\text { hidup }\end{array}$ & $\begin{array}{l}\text { Sektor peke } \\
\text { dominan da1 } \\
\text { ketergantun } \\
\text { ekonomi da1 } \\
\text { sosial }\end{array}$ \\
\hline & & $\begin{array}{l}\text { Infrastruktur dan } \\
\text { lingkungan }\end{array}$ & $\begin{array}{l}\text { Air dan energi } \\
\text { berkelanjutan, mobilitas } \\
\text { terpadu }\end{array}$ & $\begin{array}{l}\text { Mengurangi resiko dan } \\
\text { meningkatkan adaptasi }\end{array}$ & $\begin{array}{l}\text { Ketersediaa } \\
\text { kualitas air } \\
\text { ekosistem, } \\
\text { konektivitas }\end{array}$ \\
\hline
\end{tabular}


Vol 25 No 2 Tahun 2020

\begin{tabular}{|c|c|c|c|c|c|c|}
\hline Konsep & Parameter & Variabel & $\begin{array}{c}\text { Penerapan Kategori } \\
\text { Kota Tangguh dan } \\
\text { Tujuan Kota Tangguh } \\
\text { di Kota Semarang, } \\
\text { Indonesia } \\
\end{array}$ & $\begin{array}{c}\text { Penerapan Kategori } \\
\text { Kota Tangguh dan } \\
\text { Tujuan Kota Tangguh } \\
\text { di Kota Bangkok, } \\
\text { Thailand } \\
\end{array}$ & $\begin{array}{c}\text { Penerapan Kategori } \\
\text { Kota Tangguh dan } \\
\text { Tujuan Kota } \\
\text { Tangguh di Kota } \\
\text { Surat, India } \\
\end{array}$ & Keterangan \\
\hline & & & & & $\begin{array}{l}\text { pelayanan mobilitas, } \\
\text { dan regulasi, kebijakan } \\
\text { lingkungan }\end{array}$ & \\
\hline & \multirow[t]{2}{*}{$\begin{array}{l}\text { Tujuan Kota } \\
\text { Tangguh }\end{array}$} & $\begin{array}{l}\text { Memajukan } \\
\text { kepemimpinan } \\
\text { dan manajemen } \\
\text { yang efektif }\end{array}$ & $\begin{array}{l}\text { Meningkatkan koordinasi } \\
\text { antar Satuan Kerja } \\
\text { Perangkat Daerah } \\
\text { (SKPD) untuk } \\
\text { pengintegrasian data dan } \\
\text { penyampaian informasi } \\
\text { publik }\end{array}$ & $\begin{array}{l}\text { Kapasitas dan regulasi } \\
\text { kelembagaan }\end{array}$ & - & $\begin{array}{l}\text { Kota Surat di } \\
\text { India tidak } \\
\text { menerapkan } \\
\text { memajukan } \\
\text { kepemimpinan } \\
\text { dan manajemen } \\
\text { yang efektif hal } \\
\text { ini dikarenakan } \\
\text { tidak termasuk } \\
\text { dalam prioritas } \\
\text { dalam } \\
\text { menangani } \\
\text { tantangan dan } \\
\text { guncangan yang } \\
\text { dimilkik kota } \\
\text { tersebut }\end{array}$ \\
\hline & & $\begin{array}{l}\text { Memberdayakan } \\
\text { berbagai macam } \\
\text { pemangku } \\
\text { kepentingan }\end{array}$ & $\begin{array}{l}\text { Mengoptimalkan } \\
\text { Musrenbang dalam } \\
\text { proses pembangunan } \\
\text { daerah }\end{array}$ & $\begin{array}{l}\text { Meningkatkan aksi dari } \\
\text { masyarakat dan } \\
\text { penggerak komunitas } \\
\text { pada kesadaran, } \\
\text { kesiapan, dan adaptasi }\end{array}$ & - & $\begin{array}{l}\text { Kota Surat di } \\
\text { India tidak } \\
\text { menerapkan } \\
\text { memberdayakan } \\
\text { berbagai macam } \\
\text { pemangku } \\
\text { kepentingan hal } \\
\text { ini dikarenakan } \\
\text { tidak termasuk } \\
\text { dalam prioritas } \\
\text { dalam }\end{array}$ \\
\hline
\end{tabular}


Vol 25 No 2 Tahun 2020

\begin{tabular}{|c|c|c|c|c|c|c|}
\hline Konsep & Parameter & Variabel & $\begin{array}{c}\text { Penerapan Kategori } \\
\text { Kota Tangguh dan } \\
\text { Tujuan Kota Tangguh } \\
\text { di Kota Semarang, } \\
\text { Indonesia } \\
\end{array}$ & $\begin{array}{c}\text { Penerapan Kategori } \\
\text { Kota Tangguh dan } \\
\text { Tujuan Kota Tangguh } \\
\text { di Kota Bangkok, } \\
\text { Thailand } \\
\end{array}$ & $\begin{array}{c}\text { Penerapan Kategori } \\
\text { Kota Tangguh dan } \\
\text { Tujuan Kota } \\
\text { Tangguh di Kota } \\
\text { Surat, India } \\
\end{array}$ & Keterangan \\
\hline & & & & & & $\begin{array}{l}\text { menangani } \\
\text { tantangan dan } \\
\text { guncangan yang } \\
\text { dimilkik kota } \\
\text { tersebut }\end{array}$ \\
\hline & & $\begin{array}{l}\text { Membantu } \\
\text { perkembangan } \\
\text { jangka panjang } \\
\text { dan perencanaan } \\
\text { terpadu }\end{array}$ & $\begin{array}{l}\text { Meningkatkan integrasi } \\
\text { perencanaan dan } \\
\text { penganggaran daerah }\end{array}$ & $\begin{array}{l}\text { Meningkatkan } \\
\text { ketahanan terhadap } \\
\text { banjir }\end{array}$ & - & $\begin{array}{l}\text { Kota Surat di } \\
\text { India tidak } \\
\text { menerapkan } \\
\text { membantu } \\
\text { perkembangan } \\
\text { jangka panjang } \\
\text { dan perencanan } \\
\text { terpadu hal ini } \\
\text { dikarenakan } \\
\text { tidak termasuk } \\
\text { dalam prioritas } \\
\text { dalam } \\
\text { menangani } \\
\text { tantangan dan } \\
\text { guncangan yang } \\
\text { dimilkik kota } \\
\text { tersebut }\end{array}$ \\
\hline & & $\begin{array}{l}\text { Memenuhi } \\
\text { kebutuhan dasar }\end{array}$ & $\begin{array}{l}\text { Mengembangkan dan } \\
\text { mengoptimalkan } \\
\text { pengolahan air baku, } \\
\text { mendorong perilaku } \\
\text { hemat energi }\end{array}$ & $\begin{array}{l}\text { Kesehatan dan } \\
\text { kesejahteraan untuk } \\
\text { semua penduduk kota } \\
\text { sekarang dan masa } \\
\text { depan }\end{array}$ & $\begin{array}{l}\text { Penilaian spasial dari } \\
\text { permintaan pasokan } \\
\text { perumahan yang } \\
\text { terjangaku, kesadaran } \\
\text { untuk meningkatkan } \\
\text { pandangan dan } \\
\text { pemeliharaan } \\
\text { perumahan yang }\end{array}$ & \\
\hline
\end{tabular}


Vol 25 No 2 Tahun 2020

\begin{tabular}{|c|c|c|c|c|c|c|}
\hline Konsep & Parameter & Variabel & $\begin{array}{c}\text { Penerapan Kategori } \\
\text { Kota Tangguh dan } \\
\text { Tujuan Kota Tangguh } \\
\text { di Kota Semarang, } \\
\text { Indonesia } \\
\end{array}$ & $\begin{array}{c}\text { Penerapan Kategori } \\
\text { Kota Tangguh dan } \\
\text { Tujuan Kota Tangguh } \\
\text { di Kota Bangkok, } \\
\text { Thailand } \\
\end{array}$ & $\begin{array}{c}\text { Penerapan Kategori } \\
\text { Kota Tangguh dan } \\
\text { Tujuan Kota } \\
\text { Tangguh di Kota } \\
\text { Surat, India } \\
\end{array}$ & Keterangan \\
\hline & & & & & $\begin{array}{l}\text { terjangkau, dan dan } \\
\text { Rekayasa dan } \\
\text { konservasi teknologi } \\
\text { untuk menyediakan } \\
\text { perumahan yang } \\
\text { terjangkau }\end{array}$ & \\
\hline & & $\begin{array}{l}\text { Mendukung } \\
\text { mata } \\
\text { pencaharian dan } \\
\text { pekerjaan }\end{array}$ & $\begin{array}{l}\text { Mendorong penguatan } \\
\text { kerjasama Academic- } \\
\text { Bussiness-Community- } \\
\text { Government (ABCG) } \\
\text { dalam penciptaan } \\
\text { lapangan kerja, } \\
\text { Mempersiapkan } \\
\text { penyediaan tenaga kerja } \\
\text { sesuai kebutuhan pasar }\end{array}$ & - & $\begin{array}{l}\text { Mengembangkan } \\
\text { ketrampilan melalui } \\
\text { pelatihan dan } \\
\text { pembangunan kualitas }\end{array}$ & $\begin{array}{l}\text { Kota Bangkok } \\
\text { tidak } \\
\text { menerapkan } \\
\text { tujuan kota } \\
\text { tangguh } \\
\text { mendukung } \\
\text { mata } \\
\text { pencaharian dan } \\
\text { pekerjaan, } \\
\text { dikarenakan hal } \\
\text { ini tidak } \\
\text { termasuk } \\
\text { prioritas untuk } \\
\text { menangani } \\
\text { tantangan dan } \\
\text { guncangan di } \\
\text { kota ini }\end{array}$ \\
\hline & & $\begin{array}{l}\text { Memastikan } \\
\text { layanan } \\
\text { kesehatan } \\
\text { masyarakat }\end{array}$ & $\begin{array}{l}\text { Mengembangkan } \\
\text { teknologi tepat guna } \\
\text { pengendalian bencana } \\
\text { dan wabah penyakit, dan } \\
\text { Meningkatkan peran dan } \\
\text { kapasitas pemangku } \\
\text { kepentingan dalam }\end{array}$ & $\begin{array}{l}\text { Kesehatan dan } \\
\text { kesejahteraan untuk } \\
\text { semua penduduk kota } \\
\text { sekarang dan masa } \\
\text { depan }\end{array}$ & $\begin{array}{l}\text { Penelitian tentang } \\
\text { warga yang lebih sehat } \\
\text { di kota yang lebih } \\
\text { sehat }\end{array}$ & \\
\hline
\end{tabular}


Vol 25 No 2 Tahun 2020

\begin{tabular}{|c|c|c|c|c|c|c|}
\hline Konsep & Parameter & Variabel & $\begin{array}{c}\text { Penerapan Kategori } \\
\text { Kota Tangguh dan } \\
\text { Tujuan Kota Tangguh } \\
\text { di Kota Semarang, } \\
\text { Indonesia } \\
\end{array}$ & $\begin{array}{c}\text { Penerapan Kategori } \\
\text { Kota Tangguh dan } \\
\text { Tujuan Kota Tangguh } \\
\text { di Kota Bangkok, } \\
\text { Thailand } \\
\end{array}$ & $\begin{array}{c}\text { Penerapan Kategori } \\
\text { Kota Tangguh dan } \\
\text { Tujuan Kota } \\
\text { Tangguh di Kota } \\
\text { Surat, India } \\
\end{array}$ & Keterangan \\
\hline & & & $\begin{array}{l}\text { pengelolaan bencana dan } \\
\text { wabah penyakit }\end{array}$ & & & \\
\hline & & $\begin{array}{l}\text { Memajukan } \\
\text { komunitas yang } \\
\text { kohesif dan } \\
\text { terlibat }\end{array}$ & $\begin{array}{l}\text { Mendorong peningkatan } \\
\text { kualitas pendidikan } \\
\text { angkatan kerja, } \\
\text { Meningkatkan pelayanan } \\
\text { pendidikan }\end{array}$ & $\begin{array}{l}\text { Urbanisasi ramah } \\
\text { lingkungan }\end{array}$ & $\begin{array}{l}\text { Penelitian pada kohesi } \\
\text { sosial dan Kohesi } \\
\text { sosial melalui } \\
\text { kesadaran generasi }\end{array}$ & \\
\hline & & $\begin{array}{l}\text { Memastikan } \\
\text { stabilitas sosial, } \\
\text { keamanan, dan } \\
\text { keadilan }\end{array}$ & 1 & $\begin{array}{l}\text { Keamanan, aksesbilitas, } \\
\text { dan jaringan transportasi } \\
\text { yang baik }\end{array}$ & & $\begin{array}{l}\text { Kota Semarang } \\
\text { dan Kota Surat } \\
\text { tidak } \\
\text { menerapkan } \\
\text { tujuan kota } \\
\text { tangguh untuk } \\
\text { memastikan } \\
\text { stabilitas sosial, } \\
\text { keamanan, dan } \\
\text { keadilan } \\
\text { dikarenakan hal } \\
\text { ini tidak } \\
\text { prioritas untuk } \\
\text { menangani } \\
\text { tantangan dan } \\
\text { guncangan yang } \\
\text { ada di kota } \\
\text { tersebut }\end{array}$ \\
\hline & & $\begin{array}{l}\text { Membantu } \\
\text { perkembangan } \\
\text { kesejahteraan } \\
\text { ekomomi }\end{array}$ & $\begin{array}{l}\text { Mendorong } \\
\text { kewirausahaan lokal } \\
\text { dalam mewujudkan usaha } \\
\text { perdagangan dan jasa } \\
\text { yang berdaya saing, dan }\end{array}$ & $\begin{array}{l}\text { Memfasilitasi kota dan } \\
\text { komunitas berdasarkan } \\
\text { ekonomi dan } \\
\text { Memperluas } \\
\text { industrimenj, layanan }\end{array}$ & $\begin{array}{l}\text { Sektor bisnis yang tak } \\
\text { berdaya dan peluang, } \\
\text { dan Mengembangkan } \\
\text { ketrampilan melalui } \\
\text { pelatihan dan }\end{array}$ & \\
\hline
\end{tabular}


Vol 25 No 2 Tahun 2020

\begin{tabular}{|c|c|c|c|c|c|c|}
\hline Konsep & Parameter & Variabel & $\begin{array}{c}\text { Penerapan Kategori } \\
\text { Kota Tangguh dan } \\
\text { Tujuan Kota Tangguh } \\
\text { di Kota Semarang, } \\
\text { Indonesia } \\
\end{array}$ & $\begin{array}{c}\text { Penerapan Kategori } \\
\text { Kota Tangguh dan } \\
\text { Tujuan Kota Tangguh } \\
\text { di Kota Bangkok, } \\
\text { Thailand } \\
\end{array}$ & $\begin{array}{c}\text { Penerapan Kategori } \\
\text { Kota Tangguh dan } \\
\text { Tujuan Kota } \\
\text { Tangguh di Kota } \\
\text { Surat, India } \\
\end{array}$ & Keterangan \\
\hline & & & $\begin{array}{l}\text { Mengembangkan jenis- } \\
\text { jenis usaha inovatif yang } \\
\text { ramah lingkungan dan } \\
\text { bernilai sosial }\end{array}$ & $\begin{array}{l}\text { pariwisata, dan } \\
\text { perhotelan }\end{array}$ & pembangunan kualitas & \\
\hline & & $\begin{array}{l}\text { Menyediakan } \\
\text { dan } \\
\text { meningkatkan } \\
\text { aset pelindung } \\
\text { alam dan aset } \\
\text { buatan manusia }\end{array}$ & - & - & $\begin{array}{l}\text { Kebijakan dan } \\
\text { pelaksanaan dari } \\
\text { kebijakan lingkungan } \\
\text { dan Taktik inovasi } \\
\text { urbanisme untuk } \\
\text { keseimbangan } \\
\text { ekosistem }\end{array}$ & $\begin{array}{l}\text { Kota Semarang } \\
\text { dan Kota } \\
\text { Bangkok tidak } \\
\text { menerapkan } \\
\text { tujuan kota } \\
\text { tangguh } \\
\text { menyediakan } \\
\text { dan } \\
\text { meningkatkan } \\
\text { asset pelindung } \\
\text { alam dan asset } \\
\text { buatan manusia } \\
\text { dikarenakan hal } \\
\text { ini tidak } \\
\text { merupakan } \\
\text { prioritas untuk } \\
\text { menangani } \\
\text { tantangan dan } \\
\text { guncangan yang } \\
\text { dimiliki kota } \\
\text { tersebut }\end{array}$ \\
\hline & & $\begin{array}{l}\text { Memastikan } \\
\text { kesinambungan } \\
\text { dari layanan } \\
\text { kritis }\end{array}$ & $\begin{array}{l}\text { Mengembangkan dan } \\
\text { mengoptimalkan } \\
\text { pengelolaan air baku, dan } \\
\text { Mendorong inovasi } \\
\text { dalam penyediaan air }\end{array}$ & $\begin{array}{l}\text { Keamanan, aksesbilitas, } \\
\text { dan jaringan transportasi } \\
\text { yang baik }\end{array}$ & $\begin{array}{l}\text { Penelitian kualitatif } \\
\text { dan kuantitatif dan } \\
\text { pemantauan pada } \\
\text { sumber air kota, dan } \\
\text { Rekaya inovasi dan } \\
\end{array}$ & \\
\hline
\end{tabular}




\begin{tabular}{|c|c|c|c|c|c|c|}
\hline Konsep & Parameter & Variabel & $\begin{array}{c}\text { Penerapan Kategori } \\
\text { Kota Tangguh dan } \\
\text { Tujuan Kota Tangguh } \\
\text { di Kota Semarang, } \\
\text { Indonesia } \\
\end{array}$ & $\begin{array}{c}\text { Penerapan Kategori } \\
\text { Kota Tangguh dan } \\
\text { Tujuan Kota Tangguh } \\
\text { di Kota Bangkok, } \\
\text { Thailand } \\
\end{array}$ & $\begin{array}{c}\text { Penerapan Kategori } \\
\text { Kota Tangguh dan } \\
\text { Tujuan Kota } \\
\text { Tangguh di Kota } \\
\text { Surat, India } \\
\end{array}$ & Keterangan \\
\hline & & & & & $\begin{array}{l}\text { konservasi teknologi } \\
\text { untuk penyediaan air } \\
\text { dan kualitas }\end{array}$ & \\
\hline & & $\begin{array}{l}\text { Memberikan } \\
\text { komunikasi dan } \\
\text { mobilitas yang } \\
\text { andal }\end{array}$ & $\begin{array}{l}\text { Meningkatkan koordinasi } \\
\text { dan kualitas manajemen } \\
\text { kelembagaan transportasi } \\
\text { publik, dan } \\
\text { Meningkatkan integrasi } \\
\text { transportasi terpadu }\end{array}$ & $\begin{array}{l}\text { Keamanan, aksesbilitas, } \\
\text { dan jaringan transportasi } \\
\text { yang baik }\end{array}$ & \begin{tabular}{|l} 
Meningkatkan \\
mobilitas dan \\
konektivitas, dan \\
Meyakinkan kemaanan \\
infrastruktur jalan
\end{tabular} & \\
\hline
\end{tabular}




\section{KESIMPULAN DAN SARAN}

Kesimpulan yang dapat ditarik dari penelitian yang berjudul Evaluasi Kategori dan Tujuan Kota Tangguh Pada Dokumen Kebijakan Strategi Ketahanan Kota 100 Resilient City sebagai berikut:

1. Kota tangguh adalah kota yang mampu menghadapi guncangan dan tantangan yang dihadapi dengan menerapkan teori/konsep kategori dan tujuan kota tangguh dalam dokumen kebijakan strategi ketahanan sebagai pedoman untuk mewujudkan kota yang tangguh;

2. Ditemukannya parameter dan variabel yang digunakan dalam penelitian ini sebagai berikut:

a. Parameter: Kategori Kota Tangguh dan Tujuan Kota Tangguh;

b. Variabel: kepemimpinan dan strategi; kesehatan dan kesejahteraan; ekonomi dan sosial; infrastruktur dan lingkungan; memajukan kepemimpinan dan manajemen yang efektif; memberdayakan berbagai macam pemangku kepentingan, membantu perkembangan jangka panjang dan perencanaan terpadu; memenuhi kebutuhan dasar; mendukung mata pencaharian dan pekerjaan; memastikan layanan kesehatan masyarakat; memajukan komunitas yang kohesif dan terlibat; memastikan stabilitas sosial, keamanan, dan keadilan; membantu perkembangan kesejahteraan ekonomi; menyediakan dan meningkatkan asset pelindung alam dan asset buatan manuasia; memastikan kesinambungan dari layanan kritis; dan memberikan komunikasi dan mobilitas yang andal, kategori dan tujuan ini memiliki keterkaitan satu sama yang lainnya;

3. Setelah dilakukan verifikasi parameter dan variabel pada studi kasus Kota 100 Resilient City, diketahui bahwa pada dokumen kebijakan strategi ketahanan Kota Semarang, Indonesia; Kota Surat, India; dan Kota Bangkok, Thailand, ditemukannya tindakan tidak menerapkan kategori dan tujuan kota tangguh pada ketiga kota tersebut. Kota Surat merupakan kota yang paling banyak tidak menerapkan konsep kategori dan tujuan kota tangguh pada dokunen kebijakan strategi ketahanan kota yang dimilikinya. Variabel yang paling banyak tidak diterapkan adalah memastikan stabilitas sosial, keamanan, dan keadilan; serta menyediakan dan meningkatkan asset pelindung alam dan asset buatan manusia. 
Hal ini dapat terjadi dikarenakan kondisi kota dengan guncangan dan tantangan yang berbeda-beda sehingga dapat mempengaruhi penerapan teori/konsep kategori dan tujuan kota tangguh.

Saran yang diberikan sebagai upaya pemecahan temuan masalah dalam penelitian ini adalah sebagai berikut:

1. Melakukan evaluasi secara menyeluruh terhadap penerapan kategori dan tujuan kota tangguh dalam dokumen kebijakan strategi ketahanan Kota 100 Resilient City;

2. Perbaikan kualitas atau mutu pada penerapan kategori dan tujuan kota tangguh dalam dokumen kebijakan strategi ketahanan yang dimiliki oleh kota yang berstatus 100 Resilient City.

\section{DAFTAR PUSTAKA}

Ali, F. M. M., Ingirige, B., \& Zainal Abidin, N. A. (2018). Assembling and (Re)Assembling Critical Infrastructure Resilience in Khulna City, Bangladesh. Procedia Engineering, 212, 832-839. https://doi.org/10.1016/j.proeng.2018.01.107

Arup International Development. (2015). City Resilience Framework - The Rockefeller Foundation, 2014(December), $24 . \quad$ Retrieved from https://www.rockefellerfoundation.org/report/city-resilienceframework/\%5Cnhttp://publications.arup.com/publications/c/city_resilience_index

Brito, M. (2013). Evaluasi Implementasi Kebijakan Dalam Penanggulangan Bencana Banjir (Studi Kasus Di Kawasan Perumahan Pondok Gede Permai, Jatiasih, Kota Bekasi Periode 2013-2014), 1-55.

Budi Winarno (2007). Kebijakan Publik: Teori Dan Proses. Media Preindo. Jogjakarta

D’Ascanio, F., Di Ludovico, D., \& Di Lodovico, L. (2016). Design and Urban Shape for a Resilient City. Procedia - Social and Behavioral Sciences, 223, 764-769. https://doi.org/10.1016/j.sbspro.2016.05.265

Douglas, E. M., Reardon, K. M., \& Täger, M. C. (2018). Participatory action research as a means of achieving ecological wisdom within climate change resiliency planning. Journal of Urban Management, 7(3), 152-160. https://doi.org/10.1016/j.jum.2018.05.003

Eko Budi Santoso. (2013). Manajemen Risiko Bencana Banjir Kali Lamong Pada Kawasan Peri-Urban Surabaya-Gresik Melalui Pendekatan Kelembagaan. Jurnal Penataan Ruang, 8(2), 48-59. Retrieved from http://personal.its.ac.id/files/pub/5234-eko_budiurplan-Manajemen Risiko Bencana Banjir Kali Lamong.pdf

Goverment Bangkok. (2017). Resilient Bangkok. Retrieved From www.100rcbangkok.org

Hernantes, J., Sarriegi, J. M., Labaka, L., Maraña, P., \& Gimenez, R. (2018). Towards resilient cities: A maturity model for operationalizing resilience. Cities, 84(April 2018), 96-103. https://doi.org/10.1016/j.cities.2018.07.010

Kováčová, J., Pavlenko, T., Titko, M., Mitašová, V., \& Havko, J. (2017). Financing the 
Disaster Resilient City in the Slovak Republic. Procedia Engineering, 192, 301-306. https://doi.org/10.1016/j.proeng.2017.06.052

Lee, K., Chun, H., \& Song, J. (2018). New Strategies for Resilient Planning in response to Climate Change for Urban Development. Procedia Engineering, 212(2017), 840846. https://doi.org/10.1016/j.proeng.2018.01.108

Mirti Chand, A. V. (2018). Place Based Approach to plan for Resilient Cities: A local government perspective. Procedia Engineering, 212(2017), 157-164. https://doi.org/10.1016/j.proeng.2018.01.021

Orleans Reed, S., Sutarto, R., Thinphanga, P., Singh, D., Toan, V. C., \& Friend, R. (2013). "Shared learning" for building urban climate resilience - experiences from Asian cities. Environment and Urbanization, 25(2), 393-412. https://doi.org/10.1177/0956247813501136

Patton, C.V., and Sawicki, D.S., 1986, "Basic Methods of Policy Analysis and Planning", Prentice-Hall, Englewood Cliffs, New Jersey.

Pemerintah Kota Semarang. (2016). Strategi Ketahanan Kota Semarang. Retrieved From Www.100rcsemarang.Org

Pu, B., \& Qiu, Y. (2016). Emerging Trends and New Developments on Urban Resilience: A Bibliometric Perspective. Current Urban Studies, 04(01), 36-52. https://doi.org/10.4236/cus.2016.41004

Sariffuddin, S. (2015). Peluang Pengembangan Smart City Untuk Mewujudkan Kota Tangguh Di Kota Semarang. Jurnal Teknik, 36(1), 32-38.

Setiadi, R., \& Wulandari, F. (2017). Memadukan Strategi, Mewujudkan Ketahanan: Sebuah Pembelajaran Dari Pengembangan Strategi Ketahanan Kota Di Semarang. Jurnal Pengembangan Kota, 4(2), 95. https://doi.org/10.14710/jpk.4.2.95-105

Sharifi, A., \& Yamagata, Y. (2014). Resilient urban planning: Major principles and criteria. Energy Procedia, 61, 1491-1495. https://doi.org/10.1016/j.egypro.2014.12.154

Surat, Government. (2017). Surat Resilient Strategi. Retrieved From www.100rcsurat.org

Wals, J. (2015). Flood Resilient Cities - An Jakarta Case Study A Jakarta case study. Integrated Coastal Zone Management, 1-12. https://doi.org/10.13140/RG.2.1.3463.9840

Wijaya, N. (2015). Climate Change Adaption Measures in the Coastal City of Semarang, Indonesia: Current Practices and Performance. Jurnal Perencanaan Wilayah Dan Kota, 26(1), 28-42. https://doi.org/10.5614/jpwk.2015.26.1.4

Yesiana, R., Handayani, W., Anggraini, M., Vokasi, S., \& Teknik, F. (2018). Pembentukan Dan Penguatan Kelompok Siaga Bencana ( Ksb ) Sebagai Wujud Kesiapsiagaan Masyarakat Terhadap Banjir. Riptek, 12(1), 113-128. 